\title{
Hélène Campaignolle, Flaubert/Poe, réaménagement et transmission du paradigme aristotélicien
}

\section{Ida Merello}

\section{(2) OpenEdition}

\section{Edizione digitale}

URL: http://journals.openedition.org/studifrancesi/27897

DOI: 10.4000/studifrancesi.27897

ISSN: 2421-5856

\section{Editore}

Rosenberg \& Sellier

\section{Edizione cartacea}

Data di pubblicazione: 31 décembre 2006

Paginazione: 629

ISSN: 0039-2944

\section{Notizia bibliografica digitale}

Ida Merello, « Hélène Campaignolle, Flaubert/Poe, réaménagement et transmission du paradigme aristotélicien », Studi Francesi [Online], 150 (L | III) | 2006, online dal 30 novembre 2015, consultato il 08 novembre 2020. URL : http://journals.openedition.org/studifrancesi/27897 ; DOI : https://doi.org/ 10.4000/studifrancesi.27897

\section{Questo documento è stato generato automaticamente il 8 novembre 2020}

\section{(c)}

Studi Francesi è distribuita con Licenza Creative Commons Attribuzione - Non commerciale - Non opere derivate 4.0 Internazionale. 


\title{
Hélène Campaignolle, Flaubert/Poe, réaménagement et transmission du paradigme aristotélicien
}

\author{
Ida Merello
}

\section{NOTIZIA}

HÉLÈNE CAMPAIGNOLLE, Flaubert/Poe, réaménagement et transmission du paradigme aristotélicien, «Revue d'Histoire littéraire», 1, 105 année, janv-mars 2005, pp. 121-138.

1 L'A. indaga la permanenza di certi tratti del paradigma aristotelico nella narrativa occidentale anche dopo il XVII secolo, prendendo come esempio la riflessione critica di Poe tra il 1830 e il 1850 e quella di Flaubert tra il 1850 e il 1870: due autori che influenzano le teorie testuali del xx secolo. Per quanto entrambi rifiutino il modello aristotelico, la loro originalità costituisce, secondo l'A. la ripresa modernizzata dei precetti dell'arte mimetica: continuità di struttura dell'opera / concetto di unità aristotelico; progettualità di struttura / inventio e dispositio.

2 Poe non aveva sicuramente letto Aristotele, se non di seconda mano, e per rifiutarlo, eppure si ricollega alla sua poetica per il concetto di limite all'estensione dell'opera e dell'unità di impressione. 